\title{
Dynamics of ibuprofen biodegradation by Bacillus sp. B1(2015b)
}

\author{
Ariel Marchlewicz, Urszula Guzik, Danuta Wojcieszyńska* \\ Univeristy of Silesia in Katowice, Poland
}

*Corresponding author's e-mail: danuta.wojcieszynska@us.edu.pl

Keywords: ibuprofen, biodegradation, Bacillus, cometabolism, non-steroidal anti-inflammatory drug.

\begin{abstract}
High intake of over-the-counter, non-steroidal anti-inflammatory drugs, such as ibuprofen, has resulted in their presence in wastewaters and surface waters. The potentially harmful effect of ibuprofen present in the waters has led to a search for new methods of drugs' removal from the environment. One of the most important technological and economical solutions comprises microbiological degradation of these resistant pollutants. Searching for new strains able to degrade ibuprofen could be one of the answers for increasing the detection of pharmaceuticals in the waters. In this study, the ability of bacterial strain Bacillus thuringiensis B1(2015b) to remove ibuprofen is described. Bacteria were cultured in both monosubstrate and cometabolic systems with 1 , 3, 5, 7 and $9 \mathrm{mg} \mathrm{L}^{-1}$ ibuprofen and $1 \mathrm{~g} \mathrm{~L}^{-1}$ glucose as a carbon source. Bacillus thuringiensis $\mathrm{B} 1(2015 \mathrm{~b})$ removed ibuprofen up to $9 \mathrm{mg} \mathrm{L}^{-1}$ in 232 hours in the monosubstrate culture, whereas in the cometabolic culture the removal of the drug was over 6 times faster. That is why the examined strain could be used to enhance the bioremediation of ibuprofen.
\end{abstract}

\section{Introduction}

Ibuprofen (2-(4-(2-methylpropyl)phenyl)propanoic acid) is one of the most commonly used monocyclic, over-the-counter, non-steroidal anti-inflammatory drugs. So far, very few bacteria have been described as capable of degrading or biotransforming ibuprofen (Almeida et al. 2013, Chen and Rosazza 1994, Murdoch and Hay 2005). Some degradative potential was also found in white-rot fungi such as Trametes versicolor, Irpex lacteus, Ganoderma lucidum, Phanerochaete chrysosporium, Bjerkandera adusta and Bjerkandera sp. R1 (Marco-Urrea et al. 2009, Rodarte-Morales et al. 2012). Studies on activated sludge show that even a complex consortium of microorganisms is characterized by low efficiency of ibuprofen degradation (Quintana et al. 2005). Hitherto, only one biodegradation pathway for ibuprofen, by Sphingomonas sp. Ibu-2, has been proposed (Murdoch and Hay 2005). This shows how limited is the current knowledge on the microbial metabolism of non-steroidal anti-inflammatory drugs. The first stage of ibuprofen degradation, its thioesterification, is catalysed by coenzyme A ligase. Next, the removal of propionic acid chain and dioxygenation reaction leads to isobutylocatechol formation. This compound undergoes oxygenolytic cleavage (Murdoch and Hay 2005).

Ibuprofen and its hydroxylated or carboxylated derivatives have been found in influents and effluents from wastewater treatment plants (WWTP), and even in surface waters, such as rivers or lakes at a range of ng L $\mathrm{L}^{-1}$ to $\mu \mathrm{g} \mathrm{L}^{-1}$ (Buser et al. 1999, Debska et al. 2005, Ternes 1998, Öllers et al. 2001, Roberts and
Thomas 2006, Santos et al. 2010, Vieno et al. 2005, Winkler et al. 2001). It suggests that WWTPs are not able to handle with and remove this type of pollutants. For example, Jelic et al. (2011) showed that from 43 pharmaceutical compounds, 29 were detected in the effluent while 21 were present in the sludge sample. Ibuprofen content in the influents may vary from 32.822 to $2.87 \mu \mathrm{g} \mathrm{L}^{-1}$, depending on the weather and seasonal and operational conditions of the plants (Głodniok 2016, Jelic et al. 2011, Santos et al. 2010, Zając et al. 2014). The analysis of ibuprofen level in Gigablok sewage treatment plant in Katowice (Poland) showed that although the concentration of ibuprofen in the effluent was very low, its concentration in the sludge accounted half of ibuprofen concentration in the influent (Głodniok 2016). The presence of ibuprofen in the effluent and in the sludge is very important because they may be sources of this drug in rivers and in agricultural and forest land (Jelic et al. 2011). The presence of ibuprofen in the environment is a reason of documented ibuprofen chronic toxicity (Santos et al. 2010).

In this work, Bacillus thuringiensis B1(2015b), bacterium able to degrade ibuprofen, was used. Because in influents of WWTP changes in ibuprofen concentration may be observed, it was very important to evaluate the ability of the examined strain to degrade increasing concentrations of ibuprofen. It is well-known that an additional carbon source may accelerate the degradation of xenobiotics. That is why the ability of Bacillus thuringiensis B1(2015b) to degrade ibuprofen in a cometabolic system with glucose as a carbon source was also evaluated. 


\section{Material and methods}

\section{Culture medium and experimental conditions}

Bacillus thuringiensis B1(2005b) was isolated from soil contaminated by post-production wastes (the area of Chemical Factory "Organika-Azot" in Jaworzno, Poland). The bacterial strain was cultured in modified mineral medium (Kojima et al., 1961) containing (per litre): $3.78 \mathrm{~g} \mathrm{Na} \mathrm{HPO}_{4} \times 12 \mathrm{H}_{2} \mathrm{O}$, $0.5 \mathrm{~g} \mathrm{KH}_{2} \mathrm{PO}_{4}, 5.0 \mathrm{~g} \mathrm{NH}_{4} \mathrm{CL}, 0.2 \mathrm{~g} \mathrm{MgSO}_{4} \times 7 \mathrm{H}_{2} \mathrm{O}, 0.01 \mathrm{~g}$ yeast extract, $\mathrm{pH}$ 7.2. Bacteria were incubated at $30^{\circ} \mathrm{C}$ with shaking at $130 \mathrm{rpm}$.

Degradation of ibuprofen in a monosubstrate, as well as cometabolic systems, were performed in $500 \mathrm{ml}$ Erlenmeyer flasks containing $250 \mathrm{ml}$ of the mineral salts medium (Greń et al. 2010) inoculated with cells to obtain a dry-mass concentration of $0.426 \mathrm{mg} \mathrm{L}^{-1}$ and $0.053 \mathrm{mg} \mathrm{L}^{-1}$ for mono- and cometabolic systems, respectively. Ibuprofen was added to obtain the final concentration of 1, 3, 5, 7 and $9 \mathrm{mg} \mathrm{L}^{-1}$, and all cultures were incubated with shaking at $30^{\circ} \mathrm{C}$. Under experimental conditions glucose at $1 \mathrm{~g} \mathrm{~L}^{-1}$ was added as a carbon source. Bacterial growth was determined by the measurement of optical density at $\lambda=600 \mathrm{~nm}\left(\mathrm{OD}_{600}\right)$. To obtain the relationship between $\mathrm{OD}_{600}$ values and the dry-mass of bacteria a standard curve was plotted. The dependence of $\mathrm{OD}_{600}$ and dry-mass were estimated with least-squares regression (the directional coefficient was $\mathrm{a}=0.00533$ ). All experiments were performed in triplicate. The dependence between optical density and ibuprofen concentration was analyzed by one-way ANOVA $(\mathrm{p}<0.05)$ using the STATISTICA 10.0 PL software package.

\section{Chemical analysis}

For HPLC analysis the sample was centrifuged twice and supernatant was acidified with acetic acid (HPLC grade) to $\mathrm{pH}$ 3. The concentration of ibuprofen was determined by using the Merck Hitachi HPLC reversed-phase chromatograph equipped with a UV detector and an Ascentis C18 Column (150 mm $\times 4.6 \mathrm{~mm}$, particle size $5 \mu \mathrm{m}$ ). The mobile phase consisted of acetonitrile and $1 \%$ acetic acid in a ratio of $70: 30(\mathrm{v} / \mathrm{v})$ at $1 \mathrm{ml} / \mathrm{min}$ flow. The detection wavelength was set at $230 \mathrm{~nm}$. LOD and LOQ values were 0.01 and $0.05 \mathrm{mg} \mathrm{mL}^{-1}$, respectively. The glucose concentration was determined by the anthrone colorimetric method (Roe 1955).

\section{Results and discussion}

\section{Ibuprofen degradation in monosubstrate culture}

Many microorganisms are able to use xenobiotics as a sole carbon and energy source. So far, only Murdoch and Hay (2005) reported Sphingomonas sp. Ibu-2 able to grow on a medium with ibuprofen as the sole carbon and energy source. In the present study, the growth of Bacillus thuringiensis $\mathrm{B} 1(2005 \mathrm{~b})$ in the presence of various concentrations of ibuprofen was determined. We observed a decrease in the optical density of cultures in all tested concentrations of ibuprofen (Fig. 1). These results clearly indicate that ibuprofen does not stimulate bacterial growth. The ANOVA analysis did not show the influence of ibuprofen concentration on bacterial growth (Table 1). This suggests that the lack of growth does not result from the toxic effect of ibuprofen but from the fact that ibuprofen is an insufficient carbon source for the bacterial strain.
Ibuprofen was completely removed in all concentrations (Fig. 1), and degradation time was correlated with the increase concentrations. $1 \mathrm{mg} \mathrm{L}^{-1}$ of ibuprofen was degraded within 15 hours. The degradation time was extended up to 232 hours for $9 \mathrm{mg} \mathrm{L}^{-1}$. Almeida et al. (2013) described the bacterial strain, Patulibacter sp. I11, which also did not grow on ibuprofen as the sole carbon source. However, this strain decomposed ibuprofen in concentrations of $1 \mathrm{mg} \mathrm{L}^{-1}, 0.25 \mathrm{mg} \mathrm{L}^{-1}$ and $0.05 \mathrm{mg} \mathrm{L}^{-1}$ to $28 \%, 50 \%$ and $62 \%$, respectively. Noteworthy is the fact that multicultures of activated sludge were also not able to use ibuprofen as a carbon source (Collado et al. 2012, Ferrando-Climent et al. 2012, Quintana et al. 2005). FerrandoCliment et al. (2012) and Collado et al. (2012) showed that the ibuprofen removal rate was correlated with biomass concentration. When a high amount of biomass (1000 $\left.\mathrm{mg} \mathrm{L}^{-1}\right)$ was used, $1 \mathrm{mg} \mathrm{L}^{-1}$ of this drug was removed during 24 hours. For lower amounts of biomass total removal of $0.01 \mathrm{mg} \mathrm{L}^{-1}$ was not achieved even during 72 hours (Collado et al. 2012, Ferrando-Climent et al. 2012).

\section{Ibuprofen degradation in the presence of glucose}

It is generally known, that xenobiotics, particularly those resistant to degradation, may be transformed in the presence of easy to assimilate organic substrates. Supplementation of the culture with growth substrates such as glucose, acetate or glutamate is necessary for biomass enhancement, and may activate some non-specific enzymes (Greń et al. 2010). Nowadays, very few microorganisms have been described as capable of removing ibuprofen in the presence of other carbon sources (Almeida et al. 2013, Marco-Urrea et al. 2009, Murdoch and Hay 2005).

In the present study, glucose was selected as a simple carbon source. This compound stimulated Bacillus thuringiensis B1(2015b) growth. Complete glucose utilization during 16 hours resulted in bacterial growth corresponding with optical density of 0.83 (Fig. 2a), and it was in consonance with $0.436 \mathrm{mg} \mathrm{L}^{-1}$ of cell dry mass. Ibuprofen degradation was more effective in the presence of glucose (Fig. 2). The weakest effect was found for the lowest ibuprofen concentration. Removal of $1 \mathrm{mg} \mathrm{L}^{-1}$ ibuprofen in the presence of glucose was only 1 hour shorter than degradation without glucose (Fig 2b). Greater differences were observed at higher concentration of the drug. In the presence of glucose, 3,5 and $7 \mathrm{mg} \mathrm{L}^{-1}$ of ibuprofen was removed within 22, 24 and 28 hours, respectively (Fig. 2c-e), while in the cultures without glucose, the removal times were 42, 72 and 120 hours, respectively (Fig.1 b-d). The highest difference between ibuprofen degradation times was observed at $9 \mathrm{mg} \mathrm{L}^{-1}$. In the presence of glucose, the removal time decreased from 232 to 35 hours (Fig. 1e, Fig. 2f).

Otherauthorsalsoobserved enhancedibuprofen degradation after use of an additional carbon source. The white-rot fungus, Trametes versicolor was described as a microorganism capable of biotransforming $8 \mathrm{mg} \mathrm{L}^{-1}$ ibuprofen in the presence of $8 \mathrm{mg}$ $\mathrm{L}^{-1}$ glucose in 2 hours (Marco-Urrea et al. 2009). However, ibuprofen metabolites such as hydroxyibuprofen isomers were still identified after 7 days of culture. In the presented study, one metabolite, probably 2-hydroxyibuprofen, was formed during the degradation of ibuprofen, but 24 hours after ibuprofen removal it was no longer detected. Quintana et al. (2005) obtained $5 \mathrm{mg} \mathrm{L}^{-1}$ ibuprofen degradation during 15 days by activated sludge supplemented with powdered milk. Chen 

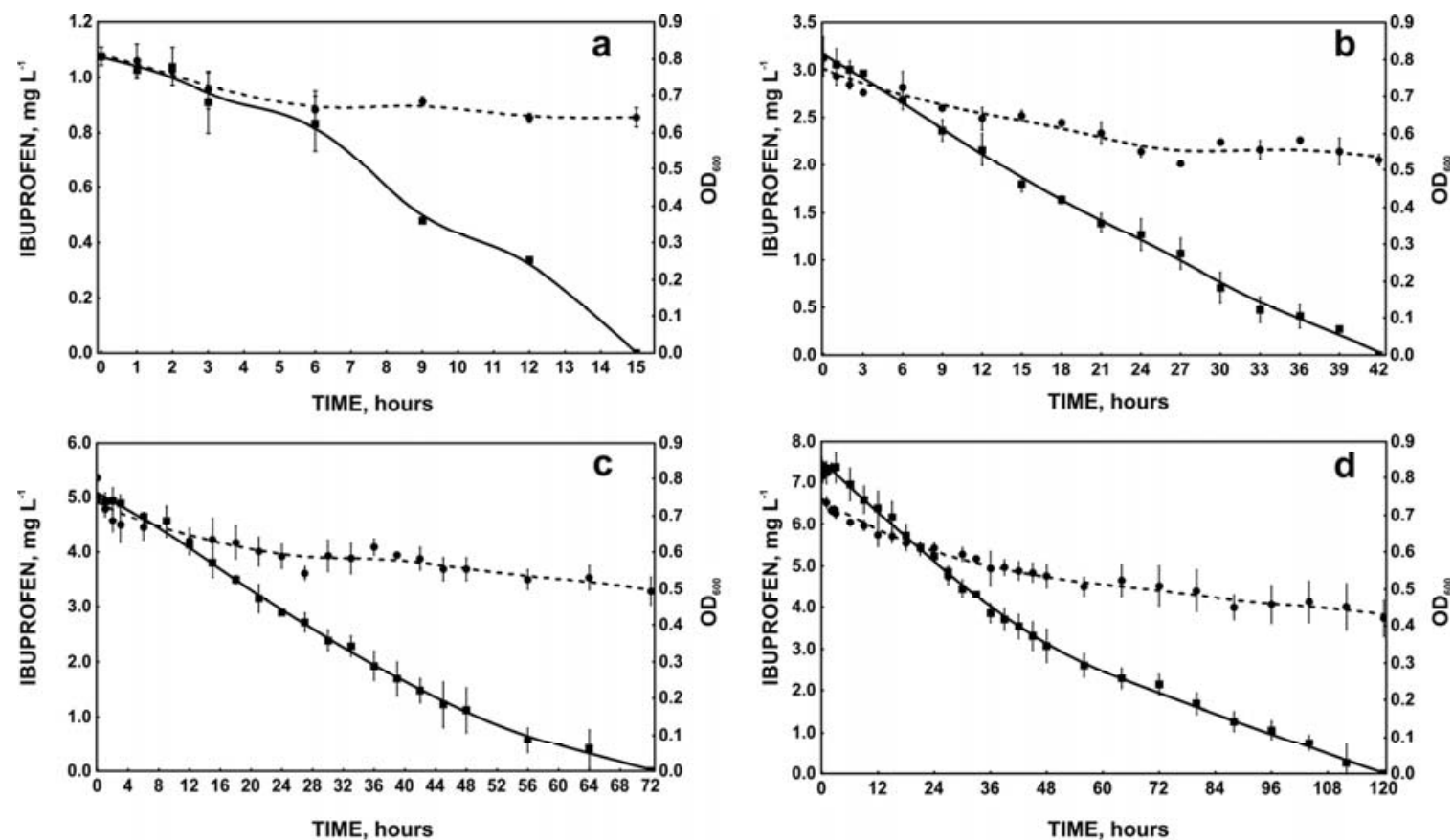

TIME, hours

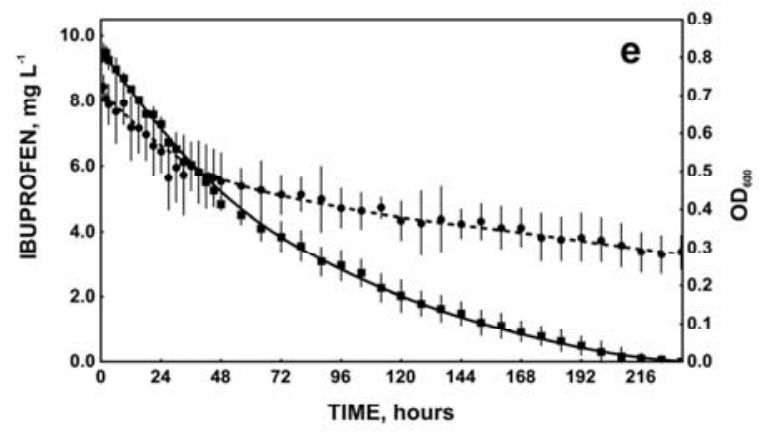

, Ibuprofen; O, Optical density

Fig. 1. Ibuprofen degradation in monosubstrate culture of Bacillus thuringiensis $\mathrm{B} 1(2015 \mathrm{~b})$ and changes in microbial biomass monitored as optical density at $600 \mathrm{~nm}$. Ibuprofen concentrations: (a) $1 \mathrm{mg} \mathrm{L}^{-1}$; (b) $3 \mathrm{mg} \mathrm{L}^{-1}$; (c) $5 \mathrm{mg} \mathrm{L}^{-1}$; (d) $7 \mathrm{mg} \mathrm{L}^{-1}$; (e) $9 \mathrm{mg} \mathrm{L}^{-1}$

Table 1. ANOVA analysis of $O D_{600}$ values versus various ibuprofen concentrations

\begin{tabular}{|c|c|c|c|c|c|}
\hline \multirow{2}{*}{$\begin{array}{l}\text { Time of } \\
\text { growth, h }\end{array}$} & \multicolumn{5}{|c|}{ Ibuprofen concentration, $\mathrm{mg} \mathrm{L}^{-1}$} \\
\hline & 1 & 3 & 5 & 7 & 9 \\
\hline 0 & $0.805 \pm 0.005$ & $0.803 \pm 0.015$ & $0.801 \pm 0.006$ & $0.802 \pm 0.006$ & $0.795 \pm 0.006$ \\
\hline 12 & $0.639 \pm 0.012$ & $0.640 \pm 0.030$ & $0.631 \pm 0.035$ & $0.645 \pm 0.031$ & $0.615 \pm 0.085$ \\
\hline 15 & $0.641 \pm 0.015$ & $0.648 \pm 0.014$ & $0.634 \pm 0.060$ & $0.643 \pm 0.018$ & $0.614 \pm 0.065$ \\
\hline 24 & $x$ & $0.552 \pm 0.014$ & $0.589 \pm 0.032$ & $0.610 \pm 0.016$ & $0.552 \pm 0.055$ \\
\hline 36 & $x$ & $0.584 \pm 0.004$ & $0.614 \pm 0.022$ & $0.555 \pm 0.046$ & $0.513 \pm 0.064$ \\
\hline 48 & $x$ & $x$ & $0.554 \pm 0.031$ & $0.535 \pm 0.032$ & $0.474 \pm 0.075$ \\
\hline 72 & $x$ & $x$ & $0.493 \pm 0.040$ & $0.484 \pm 0.052$ & $0.439 \pm 0.051$ \\
\hline 96 & $x$ & $x$ & $x$ & $0.458 \pm 0.052$ & $0.404 \pm 0.050$ \\
\hline 120 & $x$ & $x$ & $x$ & $0.420 \pm 0.049$ & $0.371 \pm 0.050$ \\
\hline
\end{tabular}

* - Statistically significant differences, $x$ - complete removal of ibuprofen

and Rosazza (1994) described a bacterium, Nocardia sp. NRRL 5646, able to metabolize $1 \mathrm{~g} \mathrm{~L}^{-1}$ of ibuprofen in soybeanglucose medium during 120 hours.

In conclusion, only a few microorganisms have been described in the literature as capable to biodegrade or biotransform ibuprofen. Bacillus thuringiensis B1(2015b) has a considerable potential for ibuprofen removal, especially in the presence of glucose. In this experimental setting, 2-hydroxyibuprofen was detected as an intermediate, and it was further metabolized. Because hydroxylated derivatives 

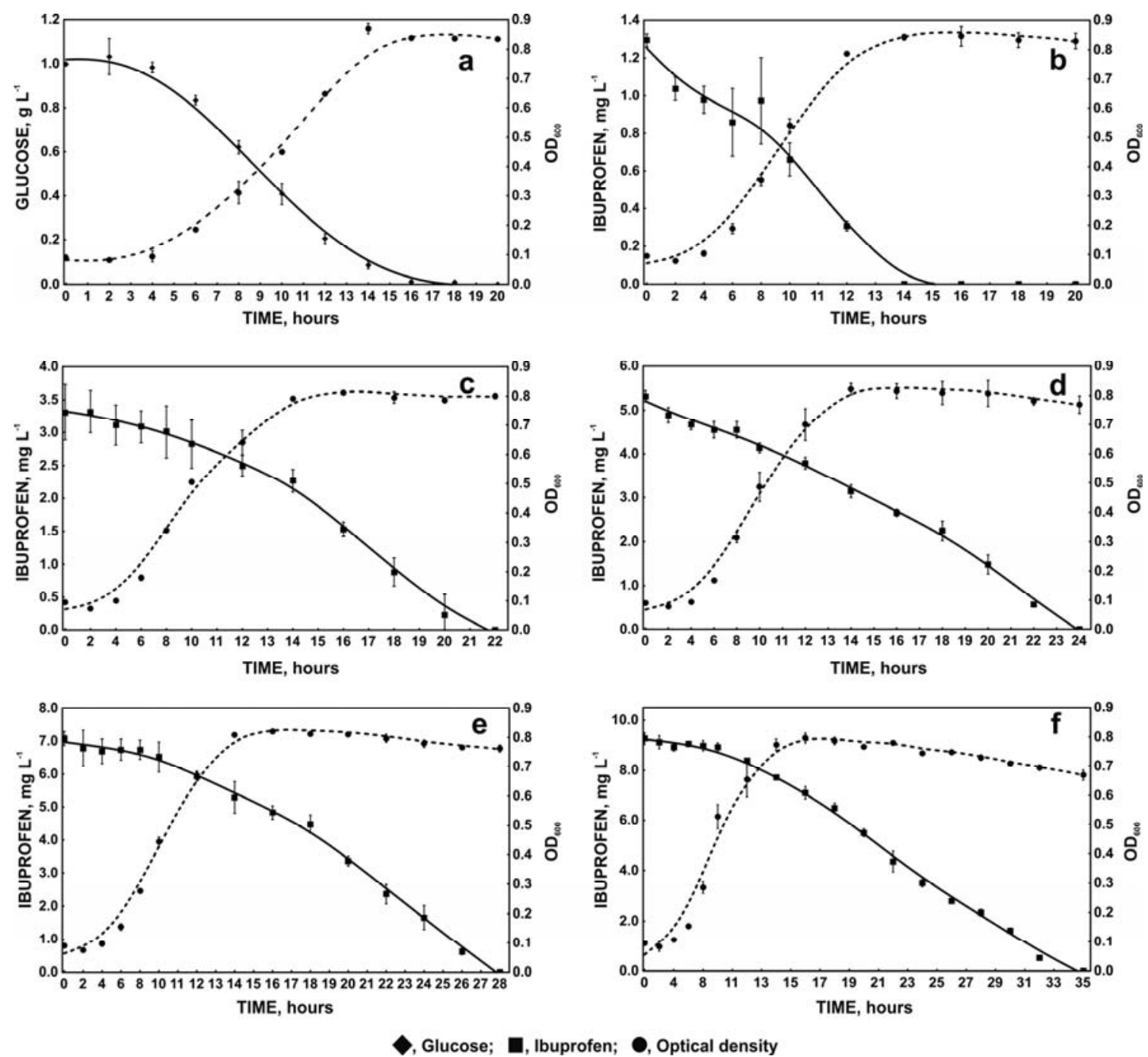

Fig. 2. Changes in microbial biomass monitored as an optical density at $600 \mathrm{~nm}$ and degradation of $1 \mathrm{~g} \mathrm{~L}^{-1} \mathrm{glucose}_{\text {(a) }}$ and ibuprofen degradation in the presence of $1 \mathrm{~g} \mathrm{~L}^{-1}$ glucose by Bacillus thuringiensis $\mathrm{B} 1(2015 \mathrm{~b})$. Ibuprofen concentrations: (b) $1 \mathrm{mg} \mathrm{L}^{-1}$; (c) $3 \mathrm{mg} \mathrm{L}^{-1}$; (d) $5 \mathrm{mg} \mathrm{L}^{-1}$; (e) $7 \mathrm{mg} \mathrm{L}^{-1}$; (f) $9 \mathrm{mg} \mathrm{L}^{-1}$

of ibuprofen are more toxic than the parent compound, the ability of the examined strain to metabolize these derivatives is also a very desirable feature. Therefore, Bacillus thuringiensis $\mathrm{B} 1(2015 \mathrm{~b})$ is a potentially useful bacterium in the biodegradation of pharmaceutical pollutants.

\section{Acknowledgments}

This work was financed by the National Science Centre (Poland) granted on the basis of decision DEC-2013/09/B/ NZ9/00244.

\section{References}

Almeida, B., Kjeldal, H., I. Lolas, Knudsen, A.D., Carvalho, G., Nielsen, K.L., Barreto Crespo, M.T., Stensballe, A. \& Nielsen, J.L. (2013). Quantitative proteomic analysis of ibuprofen-degrading Patulibacter sp. strain I11, Biodegradation, 24, 5, pp. 615-630.

Buser, H.R., Poiger, T. \& Muller, M.D. (1999). Occurrence and environmental behavior of the chiral pharmaceutical drug ibuprofen in surface waters and in wastewater, Environmental Science and Technology, 33, 15, pp. 2529-2535.
Chen, Yi. \& Rosazza, J.P.N. (1994). Microbial transformation of ibuprofen by a Nocardia species, Applied and Environmental Microbiology, 60, 4, pp. 1292-1296.

Collado, N., Buttiglieri, G., Ferrando-Climent, L., Rodriguez-Mozaz, S., Barceló, D., Comas, J. \& Rodriguez-Roda, I. (2012). Removal of ibuprofen and its transformation products: experimental and simulation studies, Science of the Total Environment, 433, pp. 296-301.

Debska, J., Kot-Wasik, A. \& Namiesnik, J. (2005). Determination of nonsteroidal antiinflammatory drugs in water samples using liquid chromatography coupled with diode-array detector and mass spectrometry, Journal of Separation Science, 28, 17, pp. 2419-2426.

Ferrando-Climent, L., Collado, N., Buttiglieri, G., Gros, M., Rodriguez-Roda, I., Rodriguez-Mozaz, S. \& Barceló, D. (2012). Comprehensive study of ibuprofen and its metabolites in activated sludge batch experiments and aquatic environment, Science of Total Environment, 438, pp. 404-413.

Głodniok, M. (2016). Occurrence of ibuprofen in wastewater treatment plant in Katowice agglomeration, Przemyst Chemiczny, 95, pp. 1000-1003 (in Polish).

Greń, I., Wojcieszyńska, D., Guzik, U., Perkosz, M. \& Hupert-Kocurek, K. (2010). Enhanced biotransformation of mononitrophenols by Stenotrophomonas maltophilia KB2 in the presence of aromatic 
compounds of plant origin, World Journal of Microbiology and Biotechnology, 26, pp. 289-295

Jelic, A., Gros, M., Ginebreda, A., Cespedes-Sanchez, R., Ventura, F., Petrovic, M. \& Barcelo, D. (2011). Occurrence, partition and removal of pharmaceuticals in sewage water and sludge during wastewater treatment, Water Research, 45, pp. 1165-1176.

Kojima, Y., Itada, N. \& Hayaishi, O. (1961). Metapyrocatechase: a new catechol-cleaving enzyme, The Journal of Biological Chemistry, 236, 8, pp. 2223-2228.

Marco-Urrea, E., Pérez-Trujillo, M., Vicent, T. \& Caminal, Gl. (2009). Ability of white-rot fungi to remove selected pharmaceuticals and identification of degradation products of ibuprofen by Trametes versicolor. 2008, Chemosphere, 74, 6, pp. 765-772.

Murdoch, R.W. \& Hay, A.G. (2005). Formation of catechols via removal of acid side chains from ibuprofen and related aromatic acids, Applied and Environmental Microbiology, 71, 10, pp. 6121-6125.

Öllers, S., Singer, H.P., Fässler, P. \& Müller, S.R. (2001). Simultaneous quantification of neutral and acidic pharmaceuticals and pesticides at the low-ng/l level in surface and waste water, Journal of Chromatography A, 911, 2, pp. 225-234.

Quintana, J., Weiss, S. \& Reemtsma, T. (2005). Pathways and metabolites of microbial degradation of selected acidic pharmaceutical and their occurrence in municipal wastewater treated by a membrane bioreactor, Water Research, 39, 12, pp. 2654-2664.

Roberts, P. \& Thomas, K. (2006). The occurrence of selected pharmaceuticals in wastewater effluent and surface waters of the lower tyne catchment, Science of the Total Environment, 356, 1-3, pp. 143-153.

Rodarte-Morales, A.I., Feijoo, G., Moreira, M.T. \& Lema, J.M. (2012). Biotransformation of three pharmaceutical active compounds by the fungus Phanerochaete chrysosporium in a fed batch stirred reactor under air and oxygen supply, Biodegradation, 23, 1, pp. $145-156$.

Roe, J.R. (1955). The determination of sugar in blood and spinal fluid with anthrone reagent, The Journal of Biological Chemistry, 212, pp. 335-343.

Santos, L.H.M.L.M., Araujo, A.N., Fachini, A., Pena, A., Delerue-Matos, C. \& Montenegro, M.C.B.S.M. (2010). Ecotoxicological aspects realted to the presence of pharmaceuticals in the aquatic environment, Journal of Hazardous Materials, 175, pp. 45-95.

Ternes, T.A. (1998). Occurrence of drugs in german sewage treatment plants and rivers, Water Research, 32, 11, pp. 3245-3260.

Vieno, N.M., Tuhkanen, T. \& Kronberg, L. (2005). Seasonal variation in the occurrence of pharmaceuticals in effluents from a sewage treatment plant and in the recipient water, Environmental Science and Technology, 39, 21, pp. 8220-8226.

Winkler, M., Lawrence, J.R. \& Neu, T.R. (2001). Selective degradation of ibuprofen and clofibric acid in two model river biofilm systems, Water Research, 35, 13, pp. 3197-3205.

Zając, A., Zembrzuska, J., Ginter-Kramarczyk, D. \& Kruszelnicka, I. (2014). Biodegradation of nonsteroidal anti-inflammatory drugs in wastewater treatment processes in large urban areas, Przemyst Chemiczny, 93, pp. 2265-2269. (in Polish)

\section{Dynamika rozkładu ibuprofenu przez szczep Bacillus thuringiensis B1(2015b)}

Streszczenie: Wysokie spożycie niesteroidowych leków przeciwzapalnych, takich jak ibuprofen, skutkuje ich obecnością w ściekach i wodach powierzchniowych. Potencjalnie szkodliwy wpływ obecności ibuprofenu w wodach wymusza konieczność poszukiwania nowych metod usuwania leków ze środowiska. Jedną z najbardziej obiecujących, między innymi ze względu na niskie koszty, jest metoda mikrobiologicznego oczyszczania. Z tego względu poszukuje się mikroorganizmów o zwiększonych zdolnościach degradacyjnych ibuprofenu. Celem pracy było określenie zdolności szczepu Bacillus thuringiensis B1(2015b)do degradacji ibuprofenu. Hodowle bakterii prowadzono w układach mono- i disubstratowych z 1, 3, 5, 7 i $9 \mathrm{mg} \mathrm{L}^{-1}$ ibuprofenu oraz $1 \mathrm{~g} \mathrm{~L}^{-1}$ glukozy jako źródłem węgla w układach kometabolicznych. Wykazano, że szczep Bacillus thuringiensis B1(2015b) usuwa $9 \mathrm{mg} \mathrm{L}^{-1}$ ibuprofenu w 232 godziny w układzie monosubstratowym, podczas gdy w hodowli kometabolicznej całkowite usunięcie ibuprofenu zachodziło 6-krotnie szybciej. Otrzymane wyniki wskazują na możliwość zastosowania badanego szczepu w bioremediacji środowisk zanieczyszczonych ibuprofenem. 